\title{
Predictors of Attitudinal Outcomes in Mobile Advertising in Sri Lanka: An Emerging Market
}

\author{
Vilasini De Silva ${ }^{12} \&$ Jun $_{\text {Yan }}{ }^{1}$ \\ ${ }^{1}$ School of Management, Huazhong University of Science and Technology, Wuhan, China \\ ${ }^{2}$ Deptartment of Marketing Manageemnet, Sabaragamuwa University of Sri Lanka, Sri Lanka \\ Correspondence: Vilasini De Silva, Doctoral Student, School of Management, Huazhong University of Science \\ and Technology, Luoyu Road, 1037, Wuhan 43071, China. E-mail: vilasini17@gmail.com
}

Received: February 21, 2016 Accepted: March 18, 2016 Online Published: May 24, 2016

doi:10.5539/ijms.v8n3p129 URL: http://dx.doi.org/10.5539/ijms.v8n3p129

\begin{abstract}
Mobile media has been rapidly evolving in the market with novel technological features. It has captured the advertising field in a revolutionary manner. Unlike in developed countries mobile media is less popular in developing countries. This study has been designed to explore the Sri Lankan consumers' attitudes towards mobile advertising. Self-administrative questionnaire was applied to collect data and 413 valid responses were gathered. The results show that, i) Demographics (age, family income) and ii) Experience with internet advertisements are predictors of attitude towards mobile advertising. Experience with internet advertisements has significant moderating effect on attitude on mobile advertising.
\end{abstract}

Keywords: mobile advertising, demographics, experience with Internet advertisements, attitudes towards mobile advertisements

\section{Introduction}

The Mobile advertising market is growing along with the spread of smartphone demand and $3 \mathrm{G} / 4 \mathrm{G}$ mobile broadband technologies (Kim \& Lee, 2014). According to Gartner (2014) the worldwide mobile advertising revenue is forecasted to reach $\$ 11.4$ billion in 2013 and it is expected to rise to $\$ 24.5$ billion in year 2016 . Interestingly, smartphones/other handheld devices extend the mobile advertising market across geographical regions as increasing population increases share of time spent on mobile devices. Especially, Asia/Pacific region is giving an early lead in mobile advertising worldwide. Gartner said mobile advertising will grow mostly in the emerging markets of Latin America, Eastern Europe, Middle East and Africa, and in large markets such as Russia, Brazil and Mexico. From 2015, it expects growth rates in this region to exceed the worldwide average, as smartphone adoption continues to grow. One aspect of major interest in international m-advertising is, as mobile technology becomes a worldwide phenomenon and mobile carriers and content providers begin to perform on a global scale (Liu, Sinkovics, Pezderka, \& Haghirian, 2012).

Mobile devices are attractive media for directly communicating with consumers who have become busier and more difficult to reach (Leek \& Christodoulides, 2009). This direct communication could be one of best investments an organization could ever have. It allows advertisers to elicit an immediate and direct consumer response (Leek \& Christodoulides, 2009). New business models for mobile marketing are turning the mobile phone into a marketer-exclusive platform (Friedrich et al., 2009). Marketers can create mobile portals dedicated to their business or brand (giving their message exclusive airtime with their best customers), a choice of tailored handsets (to match the brand), preloaded applications that drive further contact with the brand, and any number of other developing technologies that drive home exclusivity of the message (Friedrich et al., 2009).

The Mobile Marketing Association (MMA) defines mobile marketing as "the use of wireless media as an integrated content delivery and direct response vehicle within a cross media or standalone marketing communications program" (MMA, 2006). Increasingly, brand managers view mobile devices as an attractive platform from which to interact with consumers through various forms of marketing communications, including location-based promotions and television-style advertising (Gao et al., 2010). Mobile technologies are also versatile and interactive allowing users to share text-based information, as well as media (e.g., images, audio, and video) from the world around them without any time delay or the need for additional technology or expertise 
(Coursaris \& Sung, 2012, pp. 1128-1146).

As mobile advertising is becoming popular in emerging markets, lots of investigations are given attention to understand the behavioral aspects of mobile advertising. However, reports from new emerging market are insufficient. The present research pays attention to the determinants of Sri Lankan consumers' attitudes towards mobile advertising. Sri Lanka is an emerging market in South Asia with 22 million populations. Mobile advertising is really a promising industry as mobile usage has been increasing rapidly in the country. As a pilot research on mobile advertisements in Sri Lanka, we focus on the influential demographic variables in relation to attitude towards mobile advertising and initiate bridging the research gaps in mobile advertising in emerging market.

\section{Why Mobile Advertising?}

Mobile marketing has exploded worldwide with mobile device/phone penetration reaching six billion (Banerjee \& Dholakia, 2012, pp. 198-214). From global perspective, Gartner (2014) reports, worldwide mobile advertising revenue is to reach $\$ 24.5$ billion in 2016. According to the 2012 Mobile Advertising Survey by Hipcricket (www.hipcricket.com), 46 per cent of smartphone owners have viewed a mobile ad, and 64 per cent of those who have viewed an ad have made a purchase as a result of mobile advertising. Among those who have viewed a mobile ad, the type of ad viewed was as Mobile banner: 70 per cent, SMS/text message: 44 per cent, AD within a mobile game or app: 42 per cent, Mobile video: 38 per cent, and Mobile email: 31 per cent (www.hipcricket.com).

Accelerating numbers in revenue implies that mobile advertising is over-taking traditional media with its unique characteristics. Some motivations for companies to migrate towards mobile platforms are the possibilities the technology offers for establishing a relatively more personal and interactive communication with their consumers at lesser cost and create strategies that are specific to the location of a consumer within a context of consumption (Meyll et al., 2014).

Traditional advertising media like TV, radio, print, billboard and other displays carry few advantages and more disadvantages compared to mobile advertising. Traditional forms of advertising can reach large amount of consumers across multiple consumer groups, reaching consumers that may not use internet frequently or at all. But this traditional reach is not interactive as interaction in mobile advertising. Interactive communication between business and consumers is crucial in the contemporary business world. Interactivity feature of mobile advertising provides consumers opportunity to gain more knowledge about the business. These traditional advertising platforms have long life and their success had been proven over the time. Finally, creativity is an unique feature of traditional advertising media which presents the business to the world in a memorable way compared to mobile advertising. However, traditional advertising has to compete in a highly competitive environment and its sustainability is temporary. And these advertisements are flooded easily. Further, most traditional advertising methods are quite expensive and sometimes it may either not be possible for businesses to use. Nevertheless, creating and sending mobile advertising are less costly and it has a specific target to deal with. Given these possibilities and benefits marketers as well as consumers have been addicted to use mobile beyond their basic communication needs and wants.

\section{Theoretical Background of the Study (How Consumers form Attitudes towards Mobile Advertising)}

3.1 Theory of Reasoned Action as a Theoretical Framework for the Consumers' Attitude towards Mobile Advertising

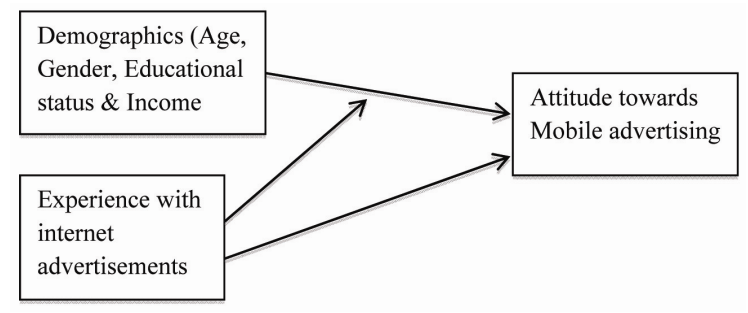

Theory of Reasoned Actions (TRA) (Fishbein \& Azjen, 2005, pp. 173-223) and its extensions (Theory of Planned Behavior) are the mostly used conceptual models in predicting consumers' behaviour towards particular stimuli. The reasoned action (Azjen \& Fishbien, 2005, pp. 173-223) is a process which describes how people 
arrive at their intentions and predict social behavior. Before arriving at intentions people form attitude on the basis of their beliefs hold on toward performance. According to Azjen \& Fishbein (2005) it is assumed that attitude is the key to understanding human behavior since human behaviour is guided by social attitudes. Therefore attitude wouldn't be necessarily an end state of a consumer towards a stimulus. On the other hand, it could act as a mediator of particular behaviour.

These beliefs and attitudes towards performance of a given behaviour is influenced by a wide variety of cultural, personal, and situational factors according to Azjen \& Fishbein (2005). Therefore, differences in beliefs and attitudes could be found between men and women, rich and poor, educated and uneducated, dominant and submissive, young and old, etc. A section of the theory has been used in the present study since this is a baseline study about mobile advertising in Sri Lanka. The interaction between socio-demographic variables has been considered along with experience with internet advertisements. Experience with internet advertisements was considered as exposure to media and other interventions in the theory.

The interaction between socio-demographic variables (such as age, gender, educational and social background) and the TRA and TPB constructs has rarely received attention in the literature in general (Botetzagias et al., 2015) since studies focuses on such to be considered as primitive. But still, studying consumer behaviour using socio-demographics bares gravity since it poses or influences real possibilities/constraints that individuals face. And, to the authors' best knowledge, no prior studies were taken place in relation to mobile advertising and its behavioral aspects in Sri Lanka as mobile advertising are not in use immensely. Based on these particular facts, the present study has been conducted only to investigate Sri Lankan consumers' attitude towards mobile advertising. Authors used literature from other relevant areas to formulate hypotheses based on the TRA.

\section{Literature Review and Hypotheses Development}

\subsection{Consumers' Demographics and Mobile Media Usage}

Most contemporary consumers do not need or want a service that provides general information; consumers would like a service that offers relevant information to simplify their hectic lives (Peter et al., 2007). Besides, Muk (2007) emphasized that mobile marketers may also develop customised strategies that make mobile marketing appealing to their target audience. Accordingly, companies need specific information about consumers to deliver more personalized information. Peter \& associates (2007) further stated that, to ensure that personalized messages are accurate in targeting interested parties, successful companies would need sophisticated customers relationship management systems that compile participants' demographics, lifestyle characteristics, brand preferences, and purchase behavior. Hence, prevalence of studies in demographics are very much essentials as baseline studies in understanding consumer behavior in any market segment.

\subsubsection{Age}

Youth and mobile media is an interest of many researchers since it is assumed that youth is the mostly interested group about new technology usage. Mobile phone culture is particularly highly associated with young people, especially text messaging (Goggin, 2013, p. 83). Mobile media is highly appreciated by young people as they confront restrictions from social groups like their parents, families, communities, and institutions (school). As explained by Porter and colleagues (2012) in their study in South Africa, the virtual mobility of the mobile phone not only promotes young people's inclusion in existing social networks but may also encourages the extension of social networks with exciting possibilities. A study of Walsh et al. (2009) to explore the support for the role of social identification processes in mobile phone use amongst youth. The study reveals that belongingness motives were related to frequent mobile phone use amongst young people.

Unal et al. (2011) illustrated differences between attitudes and behavior of youth and adults towards mobile advertising. Youth are more likely to be positive towards mobile advertising and more willing to accept advertisements on their mobiles (Unal et al., 2011). Further, Hanely and others (2006) testified that monetary incentives promote the acceptance rate of the mobile ad among youth. The current study attempts to search the relationship between age of Sri Lankan consumers and their attitudes toward mobile advertising. Consequently, the following research hypothesis is proposed for the current study.

H1: Age is a predictor of attitude of consumers in Sri Lanka toward mobile advertising. Youth has more positive attitudes towards mobile advertising than others. 


\subsubsection{Gender}

Gender differences were highlighted in studies done in new technology acceptance. But findings are not consistent in different settings. Taking online shopping as an example, some studies discovered males are more positive towards online shopping than their female counterparts (Wu, 2003, p. 42; Thamizhvanan \& Xavier; 2013, pp. 17-32). While a Chinese study done by Gong and his associates (2013) revealed male and female hold similar online shopping intentions. Contrast to them, gender wasn't proved to be a significant predictor in the explanation of the behaviour of e-shoppers (Hernandez et al., 2011) and e-banking clients (Ismail \& Osman, 2012).

In particular, inconsistent findings exist in gender and mobile media adoption. Haverila (2011) concluded that female and male respondents conceptualize cell phone behavior quite similarly. In contrast, some studies concluded that females are more negative towards behavioral aspects of mobile phones. Females appear to be more concerned about the "negatives", which include issues like being embarrassed when the phone is ringing in inappropriate times (Haverila, 2011, p. 321). Nittala (2011) found that gender accounts for most of the registering behavior in SMS campaigns. However, it was reported that females are more in the 'not willing to register' group (Nittala, 2011, p. 50). Sometimes males do believe that the mobile phone is an essential component in their lives. Thus, they feel that they are attached to mobile phones and applications as well. The attachment is a significant factor which influences attitude toward mobile marketing for male youth consumers in United States and China while it is not for female youth consumers in either country (Gao et al., 2012). Further, it is apparent that males have frequent habit of using mobile phone more in their day-to-day lives. And males prefer using mobile talk more than their female counterparts do (Haste, 2005, p. 62).

Controversially, Leppaniemi \& Karjaluoto (2008) discovered that female participants are more active than male participants in responding to advertisements by sending SMS. Okazaki's (2007) empirical study in Japan found females are more likely trustful in mobile advertising than their male counterparts. Thus, we conclude $\mathrm{H} 2$ as below.

\section{$\mathrm{H}_{2}$ : Female tends to be more positive towards mobile advertising than their male counterparts.}

\subsubsection{Education}

Education has been testified to influence the adoption of new technologies by many researchers. Ndung'u et al. (2012) reported that high level of education is a significant factor in determining high level of new technology acceptance (usage of the inter-net, e-mail and mobile phones). Consumers with high level of education are likely to buy online (Morganosky et al., 2000), (Sundaram \& Taylor, 1998, pp. 440-445), (Hui \& Wan, 2007, pp. 310-316), (Wu, 2003, p. 43). A Greek study illustrated university graduates and university postgraduates mostly likely to do internet shopping (Vrechopoulos et al., 2001). Gong (2013) demonstrates undergraduates tend to do online shopping mostly and Punj (2011) concluded online shoppers tend to be more educated. Education has been also proved as a significant predictor of positive attitudes towards using online banking (Abdullah et al., 2009; Abbad et al., 2012). Likewise, usage of smartphones and its applications is highly associated with education (Kim et al., 2015). The above observation is supported by Nittala's (2011) findings that stated college students are more inspired by incentivised mobile advertising.

Unlike the observation in relationship between education and adoption of new technology, research found education is negatively related to attitude towards advertising. Many research reported less educated people are more likely to see advertising informative, be confident in using advertised information to make their purchase decisions (Shavitt et al., 1998; Dutta, 2006, p. 109). Speck \& Elliot's (1997) study illustrated highly educated people consider newspaper advertisements are annoying, unuseful, uninteresting and excessive in numbers. Consequently, we develop a pair of contradictory hypotheses on education and attitude to mobile advertising as follows.

$H_{3 a}$ : The more higher the education consumers have, the more positive they are towards mobile advertising.

$H_{3 b}$ : The more higher the education consumers have, the more negative they are towards mobile advertising.

\subsubsection{Family Income}

Antecedents of new technology acceptance have been testified immensely by researchers in various scenarios. Economic perspective (eg; family income, annual income) has been highlighted since it is accountable for most behaviours of rationale consumers. For example, in online-shopping, research studies found higher income earners are attracted more by the time-saving features of online-shopping. Higher income earners believe online shopping saves time and are attracted by the time-saving features of online shopping (Punj, 2012, p 639). It has been indicated even grocery category adopters too have high income (Hansen, 2005, p. 115). Further, internet shoppers 
could be varied depends on their other purposes as well. Bhatnagar's (2007) study revealed that high income earners likely to shop online for highly personal uses. Also, high income favours extensive home-shopping (Balabanis \& Vassileiou, 1999, pp. 361-385).

Besides time saving, it is also found higher income consumers go to online shopping with higher e-trust level (Pang et al., 2007). Gong and colleagues (2013) found income is a significant predictor in Chinese consumers' online shopping too. Internet banking is found better accepted among relatively higher income people (Maenpaa et al., 2008; Ismail \& Osman, 2012), Seyal \& Rahim (2011). In conclusion, prior research supported that income is a positive predictor of online service adoption.

However, findings in acceptance of advertising seems to support lower income people are more positive. Shavitt et al. (1998) reported lower income people has higher attitude towards advertising in USA. They observed that lower income people are less offensive to advertising. Another study suggested that consumers with higher income are less likely to like TV advertising (Alwitt \& Prabhaker, 1992, pp. 30-42). Further, Alwitt \& Prabhakar's study in 1992 indicated, wealthier viewers dislike TV advertising if they dislike format or the frequency of advertising. Speck \& Elliot (1997) either discovered that high income earners tend to avoid newspaper advertisements, magazine advertisements and TV advertisements considering they are annoying, waste of time, uninteresting and unbelievable.

Unlike other forms of pure new technology, mobile media is a hybrid of new technology and traditional advertising. Mobile media being a new platform for advertising and touching consumers at personal level bares different attitudinal outcomes. Receiving advertisements and responding to advertisements via smartphones can increase the rental/total bill paid for the service provider. Therefore, a rationale consumer confronts a trade-off between the advertising value and the amount spent to receive mobile advertising. So, a pair of contradictory hypotheses we are proposing here as $\mathrm{H}_{4 \mathrm{a}}$ and $\mathrm{H}_{4 \mathrm{~b}}$.

$H_{4 a}:$ Family income is a predictor of consumers' attitudes towards mobile advertising in Sri Lanka. Higher the family income, the more positive the attitudes towards mobile advertising.

$H_{4 b}$ : The higher the family income, the more negative the attitudes towards-advertisements.

\subsubsection{Experience with Internet Advertisements}

Prior experience of the consumers can influence their future consumption behaviour (Hawkins et al., 1998). Experience could be generated out of all kinds of behavior. Reciprocally, the experience shapes the behaviour. Individuals who used to try novel things always gather experience to their lives. Novel things brought by technological advances are likely to be tested by such individuals. It is confirmed that online shoppers are highly influenced by their prior extensively satisfied experience in the internet (Punj, 2012, p. 638; Bhatnagar, 2007, p. 99; Kim, 2012, p. 95; Monsuwe et al., 2004; Kwon, 2010, p. 346).

In Gao's (2010) study about interactivity perception of the user reported previous experience has no significant influences on user interactivity perception in mobile advertising. Interestingly, Yang et al. (2013) noted that the effect of attitude towards advertisements on actual response is much stronger in low-experience group than in the high-experience group. Thus, we deduce that people who have prior experience in consuming internet advertisements may have the same interest in mobile advertising also.

$H_{5}$ : Consumers with higher experience with the internet advertisements will have more positive attitude toward mobile advertising than those with low experience with inter-net advertisements.

\subsubsection{Moderating Effect of Experience with Internet Advertisements}

Informed by the discussion above, demographic variables (age, gender, education level and family income) are hypothesised to be predictors of attitude towards mobile advertising. And, similarly experience with internet advertisements to predict a direct relationship with attitude towards mobile advertising. The interaction of demographic variables and experience with internet advertisements may predict a different relationship with the latent variable (attitude towards mobile advertising). Given the fact that both demographic characteristics and experience with internet advertisements are possessed by consumers, a moderating effect could be assumed to exist. Thus, experience with internet advertisements is considered as a moderating variable. $\mathrm{H}_{6}$ is proposed as follows.

$H_{6}$ : There will be a significant interaction effects between age, gender, education level and family income and experience with internet advertisements on attitude towards mobile advertising. 


\section{Research Methodology}

Data collection has been carried out in Sri Lanka by self-administrative questionnaire survey. The capital city and the universities were the aimed locations. The foremost reason to select universities was, those are the places where youngsters (age group 20-25) gather from various regions of the country. Accordingly, capital city has been selected since working crowd from different areas of the country stay in the capital city and it is main commercial city of the country. The subjects were filtered by using a question item (oral) "Are you using a smartphone?" The purposive sampling technique has been utilized. 413 respondents are in the sample in total. Six items were used as measurements of Experience with Internet advertisements. Eight question items were included in the questionnaire to measure attitudes towards mobile advertisements from prior literature. The items and sources are presented in Table 1.

Table 1. Measurement of experience with internet advertisements and attitude toward mobile advertising and sources

\begin{tabular}{ll}
\hline Measurement & Source \\
\hline Attitude toward mobile advertising & \\
\hline I like to receive advertisements in my mobile & Authors-created \\
It is good to receive advertisements in my mobile & Authors-created \\
Mobile advertising provide quick and up to date information & Wang and Sun (2010),Liu et al.(2012) \\
Receiving mobile advertising is entertaining & Wang and Sun (2010), Yang et al.(2013) \\
Mobile advertising are pleasing & Wang and Sun (2010), Yang et al.(2013) \\
Mobile advertising are enjoyable & Wang and Sun (2010), Yang et al.(2013) \\
Mobile advertising are useful & Ducoffe (1995), Liu et al. (2012) \\
Mobile advertising are disturbing/irritating & Varnali et al. (2012), Yang et al.(2013) \\
\hline Experience with the internet advertisements & \\
\hline I am familiar with internet advertisements & Authors-created \\
I have clicked internet advertisements & Authors-created \\
Internet advertisements provide useful information & Ducoffe (1995), Liu et al. (2012) \\
Internet advertisements are entertaining & Wang and Sun (2010), Yang et al.(2013) \\
I have used internet advertisements to buy products and services & Hong and Cho (2011), Wu et al.(2011) \\
Internet advertisements are disturbing & Varnali et al. (2012), Yang et al.(2013 \\
\hline
\end{tabular}

\section{Results of the Analysis}

\subsection{Profile of the Sample}

Table 2 presents the profile of the sample. Age category 21-25 is the major category (36.5\%) of the sample that uses smartphones. Next is the respondents fallen in to 26-30 age group (32.4\%). There is an implication that smartphones is more popular among young people in Sri Lanka. 52.9\% of the respondents are males and $47.1 \%$ are females and $39.6 \%$ of them are following undergraduate education.

Table 2. Sample profile $(\mathrm{n}=413)$

\begin{tabular}{|c|c|c|c|c|c|c|c|c|}
\hline $\begin{array}{l}\text { Demographic } \\
\text { Characteristics }\end{array}$ & \multicolumn{2}{|c|}{ s Frequency } & \multicolumn{2}{|r|}{ Percent } & \multicolumn{2}{|c|}{$\begin{array}{l}\text { Demographic } \\
\text { Characteristics }\end{array}$} & Frequency & Percent \\
\hline \multirow[t]{6}{*}{ Age } & $16-20$ & 20 & & $4.8 \%$ & Family & $>20,000$ & 30 & $7.2 \%$ \\
\hline & $21-25$ & 151 & & $36.5 \%$ & Income & $20,001-40,000$ & 68 & $16.4 \%$ \\
\hline & $26-30$ & 134 & & $32.4 \%$ & (in SL Rupees) & $40,001-60,000$ & 92 & $22.2 \%$ \\
\hline & $31-40$ & 82 & & $19.8 \%$ & & $60,001-80,000$ & 60 & $14.5 \%$ \\
\hline & 40 above & e 26 & & $6.3 \%$ & & $80,001-100,00$ & 78 & $18.8 \%$ \\
\hline & & & & & & 100,001 above & e 79 & $19.15 \%$ \\
\hline \multirow{3}{*}{ Gender } & Male & 219 & & $52.9 \%$ & & & & \\
\hline & Female & 193 & & $47.1 \%$ & Occupation & & & \\
\hline & & & & & & Student & 178 & $43.0 \%$ \\
\hline \multirow[t]{6}{*}{ Education } & $\mathrm{GCE}(\mathrm{O} /$ & & 16 & $3.9 \%$ & & Executive & 106 & $25.6 \%$ \\
\hline & GCE (A/ & & 66 & $15.9 \%$ & & Manager & 79 & $19.1 \%$ \\
\hline & Undergr: & aduate & 164 & $39.6 \%$ & & Other & 49 & $11.8 \%$ \\
\hline & Graduate & & 67 & $16.2 \%$ & & & & \\
\hline & Postgrad & luate & 64 & $15.5 \%$ & & & & \\
\hline & Professio & onal & 36 & $8.7 \%$ & & & & \\
\hline
\end{tabular}




\subsection{Reliability of the Measurements}

Experience with the internet advertisements and Attitude toward mobile advertising constructs were examined for reliability. Alpha values $(\alpha)$ for each construct are .823 and .836 respectively. Every construct meets the rule of thumb (0.8). Descriptive statistics relevant to each variable is listed in table 3.

Table 3. Descriptive statistics of variables

\begin{tabular}{lll}
\hline Determinant & Mean & SD \\
\hline Experience & 3.19 & .64 \\
Attitude & 2.56 & .74 \\
\hline
\end{tabular}

\subsection{Hypotheses test}

6.3.1 Demographic Variables (Age, Gender, Education and Family Income) and Attitude toward Mobile Advertising

ANOVA analysis is applied to find the relationship between demographic variables and attitude towards Mobile advertising.

ANOVA (one-way) test results (see Table 4) show that age is a predictor of Sri Lankan consumers' attitude towards mobile advertising. ( $F$ value $=14.445,(p)=.000$ ). The group aged $21-25$ has the most positive attitudes towards Mobile advertising (mean=2.9 and $\mathrm{SD}=.74$ ). Subsequent is a younger group of $16-20$ years old (mean=2.7 and $\mathrm{SD}=.43$ ). The group above 40 years has the least level (mean=2.0 and $\mathrm{SD}=.80$ ) of attitudes towards Mobile advertising. $\mathrm{H} 1$ is supported by the results.

There is a gender difference in attitude towards mobile advertising $(F=11.918, p=.001)$. Females (Mean=2.7 and $\mathrm{SD}=.74$ ) are more positive than male counterparts (Mean=2.4 and $\mathrm{SD}=.72$ ). Thus, $\mathrm{H} 2$ is supported.

Education is found as a predictor of attitude towards mobile advertising $(F=12.725, p=0.000)$ (see table 4). Respondents from undergraduate category (college students) show more positive attitude towards mobile advertising (Mean=2.9, $\mathrm{SD}=.76$ ) than the higher educated groups (graduate, postgraduate and professional). The result rejects the hypothesis $\mathrm{H}_{3 \mathrm{a}}$ but hypothesis $\mathrm{H}_{3 \mathrm{~b}}$.

Family income is also a predictor of attitude of Sri Lankan consumers towards mobile advertising $(F=9.085$ and $p=0.007)$. Among all, respondents with lowest income $(>20,000)$ demonstrate the highest positive attitude towards mobile advertising (Mean=3.1 SD=.62). Therefore, hypothesis $\mathrm{H}_{4 \mathrm{a}}$ is partially supported. Higher income groups $(60,001-80,000,80,001-100,000$ and $<100,001)$ do not perceive Mobile advertising positively with mean less than the neutral point ( 2.4 in 5 point scale). The results prove $\mathrm{H}_{4 \mathrm{~b}}$, higher income earners have negative attitude towards mobile advertising.

To have a further look at the interaction on demographic variables, two-way ANOVA (GLM) was carried out. Most rationale decisions are affected by economic conditions and education of a consumer. Receiving mobile advertising requires technology orientation (to some extend) and spending on data services as well. Therefore, we considered the interaction effect of income and education on attitude towards mobile advertising. And, results show that there is no interaction effect of income and education on attitude towards mobile advertising $(\mathrm{F}=1.546$, $p=.214$ ) (Table 5)

Table 4. ANOVA (one-way) results of Demographics

\begin{tabular}{|c|c|c|c|c|c|c|c|c|c|}
\hline $\begin{array}{l}\text { Demographic } \\
\text { Characteristic }\end{array}$ & Mean & $\begin{array}{l}\text { Standard } \\
\text { Deviation }\end{array}$ & F value & $\mathrm{P}$ value & $\begin{array}{l}\text { Demographic } \\
\text { Characteristic }\end{array}$ & Mean & $\begin{array}{l}\text { Standard } \\
\text { Deviation }\end{array}$ & F value & $\mathrm{P}$ value \\
\hline Age & & & 14.445 & 0.000 & Gender & & & 1.918 & 0.001 \\
\hline $16-20$ & 2.7 & 0.43 & & & Male & 2.4 & 0.72 & & \\
\hline $21-25$ & 2.9 & 0.74 & & & Female & 2.7 & 0.74 & & \\
\hline $26-30$ & 2.4 & 0.74 & & & & & & & \\
\hline $31-40$ & 2.4 & 0.59 & & & Family & & & & \\
\hline 40 above & 2.0 & 0.80 & & & Income & & & & \\
\hline Education & & & 12.725 & 0.000 & (in Rupees) & & & 9.085 & 0.000 \\
\hline $\operatorname{GCE}(\mathrm{O} / \mathrm{L})$ & 2.5 & 0.41 & & & $>20,000$ & 3.1 & 0.62 & & \\
\hline $\operatorname{GCE}(\mathrm{A} / \mathrm{L})$ & 2.4 & 0.67 & & & $20,001-40,000$ & 2.9 & 0.88 & & \\
\hline Undergraduate & te 2.9 & 0.76 & & & $40,001-60,000$ & 2.7 & 0.67 & & \\
\hline Graduate & 2.2 & 0.59 & & & $60,001-80,000$ & 2.4 & 0.68 & & \\
\hline Postgraduate & 2.3 & 0.70 & & & $80,001-100,000$ & 2.4 & 0.65 & & \\
\hline Professional & 2.4 & 0.74 & & & $<100,001$ & 2.4 & 0.70 & & \\
\hline
\end{tabular}


Table 5. Two-way ANOVA results for interaction of education \& income variables

\begin{tabular}{lll}
\hline Group & F value & P value \\
\hline Education & 17.617 & 0.000 \\
Income & 7.423 & 0.007 \\
Education * Income & 1.546 & 0.214 \\
\hline
\end{tabular}

6.3.2 Direct and Moderator Effect of Experience with Inter-Net Advertisements and Attitude towards Mobile Advertising

Firstly we tested the direct effect of experience with internet advertisements. Taking demographics as control variables, the results of regression show that experience with internet has a direct effect $(\beta=.280, P=.000$, (see Table 6) on attitude towards mobile advertising. Consumers with higher experience with the internet advertisements have more positive attitude toward mobile advertising than those with low experience with internet advertisements. Thus, $\mathrm{H}_{5}$ is supported.

Table 6. Hierarchical regression results of direct effect of experience with internet advertisements

\begin{tabular}{lllllll}
\hline & $\begin{array}{l}\text { Independent } \\
\text { Variables }\end{array}$ & $\begin{array}{l}\text { Standardized } \\
\text { Coefficient }(\beta)\end{array}$ & $\mathrm{R}^{2}$ & $\mathrm{~F}$ & $\mathrm{t}$ & $\mathrm{P}$ \\
\hline \multirow{2}{*}{ Model 1 } & Age & -.268 & .136 & 16.018 & -4.341 & .000 \\
& Gender & .092 & & & 1.947 & .052 \\
& Education & .116 & & & 1.915 & .056 \\
& Income & -.200 & & & -3.777 & .000 \\
& & & & & & \\
\hline Model 2 & Age & -.237 & .213 & 22.069 & -4.003 & .000 \\
& Gender & .105 & & & 2.323 & .021 \\
& Education & .117 & & & 2.023 & .044 \\
& Income & -.210 & & & -4.161 & .000 \\
& Experience with & .280 & & & 6.335 & .000 \\
& Internet advertisements & & & & \\
\hline \hline
\end{tabular}

Table 7. Regression results of moderation effect of experience internet advertisements

\begin{tabular}{lllllll}
\hline & $\begin{array}{l}\text { Independent } \\
\text { Variables }\end{array}$ & $\begin{array}{l}\text { Standardized } \\
\text { Coefficient }(\beta)\end{array}$ & $\mathrm{R}^{2}$ & $\mathrm{~F}$ & $\mathrm{t}$ & $\mathrm{P}$ \\
\hline Model 3 & Exp*Age & -.210 & .125 & 14.564 & -3.026 & .003 \\
& Exp*Gender & .284 & & & 6.055 & .000 \\
& Exp*Edu & .172 & & & 2.541 & .011 \\
& Exp*Income & .114 & & & -2.037 & .042 \\
\hline
\end{tabular}

Further, we tested the moderation effect of experience with internet advertisements. The results of regression show that there is a moderating effect of experience with internet advertisements to demographic variables. Except family income, experience positively moderates the impact of age, gender and education on attitude towards mobile advertising (exp*age: $\beta=-.210, p=.003$, exp*gender: $\beta=.284$ and $\mathrm{p}=.000$, exp*edu: $\beta=.172$, $p=.011)$.

\section{Conclusion and Discussion}

We testified the role of demography on consumers' attitude towards mobile advertising in Sri Lanka. Based on data analysis results $\mathrm{H} 1, \mathrm{H} 2, \mathrm{H}_{3 \mathrm{~b}}$ and $\mathrm{H}_{4 \mathrm{~b}}, \mathrm{H} 5$ and $\mathrm{H} 6$ are supported. $\mathrm{H}_{3 \mathrm{a}}$ and $\mathrm{H}_{4 \mathrm{a}}$ are partially supported. As Fishbein's theory suggests, socio-demographic factors and exposure to internet advertisements supports Sri Lankan consumers to form attitude towards Mobile advertising. Being the baseline study about mobile advertising in Sri Lanka, the study's results enrich the literature in mobile advertising from the emerging market perspective.

Consequently, it is confirmed that age is a predictor of attitudes towards mobile advertising in Sri Lanka. Youth (21-25 year group) has more positive attitudes towards mobile advertising than elders. The finding is parallel to most of the prior research. Mobile culture is highly associated with younger generation (Goggin, 2013). Youth is the mostly interested group about mobile usage (Dhaliwal, 2003). Sending short messages is mostly popular among youth (Leppaniemi \& Karjaluoto, 2008). Youth are willing to accept mobile advertising on their mobile (Hanely et al., 2006) and young people are encouraged to extend their social networks by mobile phones (Porter 
et al., 2012). Thus, age is one of the key determinants of attitude formulation. Attitudes could be changed in relation to the age of the consumer. Especially, technology orientation is caused by the age. Results show that when age increases the level of positive attitude decreases. This finding is parallel to Unal et al. (2011). They discovered that there is a difference in attitudes between youth and adults (Unal et al., 2011). It is interesting that, the moderating effect of experience with internet advertisements on age consumers does not change the predictive role of age.

It is proved that gender is significant in influencing attitudes towards mobile advertising. The current study accounts for gender differences in attitudes of Sri Lankan consumers towards mobile advertising. Previous researches in advanced markets revealed that gender account for attitudes toward mobile advertising (Leppaniemi \& Karjaluoto, 2008; Haste, 2005; Nittala, 2014; Gao et al., 2012; Haverila, 2011). The present outcome is only parallel to findings of Gao et al. (2010). We found females are more positive than males towards mobile advertising in Sri Lanka. The moderation effect of experience on gender is significant. It refers that female consumers with higher experience are more positive to adopt mobile advertising than others. The findings are helpful for companies in targeting segmentation for their mobile communication strategy in the country as well as other emerging markets.

The survey confirmed that consumers with low education level likely to be more positive towards mobile advertising. Results are parallel to findings of Vrechopoulos (2001) and Gong (2013) who illustrate that university graduates and undergraduates likely to be most interested groups in on-line shopping. In contrast, results are opposing to the findings of Ndung'u et al. (2012), Sundaram \& Taylor (1998), Hui \& Wan (2007), and Wu (2003) who argue that on-line behavior is highly associated with high level of education.

Family income is proven as another predictor of Sri Lankan consumers' attitude towards mobile advertising. The study concludes respondents with low income level have a more positive attitude towards mobile advertising. $\mathrm{Wu}$ (2003) and Punj (2012) indicated low income likely to be attracted by money saving aspects of on-line shopping. The facts that low income tend to save money and likely to have more spare time, they prefer on-line activities which is assumed to be money saving and bring monetary benefits through varied activities (eg: coupons, competitions). But the moderating effect of experience changes this predictive role. It reduces the significance of family income in influencing the attitude towards mobile advertising.

Combining the roles of age, gender and education, we can make a conclusion that income is less important than others in segmenting the consumers for mobile advertising in emerging markets. However, combination of income and education indicates an important role in the study. Consumers with low income and low education show he highest positive attitude towards mobile advertisements. With the fast spread of smartphone in emerging markets, companies should pay more attention on 21-25 years old female college educated population when making decision in mobile marketing.

We found that consumers' experience with internet advertisements plays a vital role in shaping attitudes towards mobile advertising. Individuals with high level of experience with inter-net advertisements would have a higher interest or attitude to adopt mobile advertising too. We further found that experience has moderate role to demographics. This manner could be considered as a stimulus for an individual to try new forms of advertising media. Receiving advertisements in the mobile phone may be an interesting phenomenon to the particular person.

\section{Managerial Implications}

As a result of the rapid development of modern technology, Internet and mobile networks have become interwoven in the everyday lives of people (Chen et al., 2014). Handheld devices have started to offer different mobile services to customers and marketers too. With the advent of smartphone simple communication via mobile phones has been augmented in to various other areas like social networking, browsing, blogging, and so forth. Moreover, customers are exposed to large amount of data with this paradigm shift. This scenario has been creating countless avenues for the marketing industry while giving more preferences to customer. Contemporary customer who is well aware about happenings around the world expects the best from his/her product/service provider.

The unique differentiator of the mobile marketing platform is marketers' ability to reach consumers untethered in the context of their daily routines and lifestyles, and not just in the context of their offices or living rooms (Rohm et al., 2012). It opens up an entirely new suite of applications allowing marketers to reach consumers with contextually relevant advertising and promotions. Managers should start building strategy from overall consumers and seek to tap into the individual characteristics; marketers need to think about where their customers live, and what cultural and social forces may influence their behavior in the mobile space. To address this scenario, marketers try to use more personalized form of mobile advertising to reach customers in the world of BIG DATA. 
With increasing bandwidth and the development of smartphones, mobile advertising applications have also become personalized and diversified. Branded mobile apps (app dedicated to the brand), location-based services, in-app advertisements, and so forth are emerging strategies of marketers to reach customers more personal level.

The situation is such, marketers need ways to understand insights of mobile marketing and consumers' behavioral aspects related to mobile advertising. As consumers heavily using mobile devices and rely on such for their day to day activities, it is important for marketers to acquire a deep understanding of the concepts and phenomena connected to mobile advertising. More literature is needed as mobile technology industry is rapidly developing and more work is needed to guide firm's strategies and tactics as consumer psychology is changing with complex needs and wants.

Unsurprisingly as modern consumers expect more transparency and ways of interactivity, marketers can't rely on traditional advertising methods or communication tools anymore. To address this issue, marketers can use the inherent advantage of mobile advertising in driving consumers' response by clicks or conversation events (Rosenkrans \& Myers, 2012, pp. 5-21). Conversation type or any other action type mobile advertisements keep consumers alive and active with the advertisement. When the advertisement encompasses activities consumers are motivated to act with the advertisement which results a positive or a negative response. Mokbel and Levandoski (2009) (cited in Rosenkrans \& Myers, 2012, pp. 5-21) assert that advertising contents should be personalized or matched to users' preferences and profile.

Pervasive nature of the mobile technology and the advent of mobile advertising has opened up the possibility for marketers to reach individual consumer in the correct place, at the perfect time, and in interactive way (Peters et al., 2007; as cited in Yu, 2013, p. 6). Companies try to integrate mobile advertisements as a promotional tool in their promotional mix for number of reasons. Number of mobile phones users is increasing rapidly. Additionally, smartphones users are growing in numbers too. Mobility of the mobile media and the ease of reaching the target audience are the other reasons why companies use mobile advertising as one of their marketing tools. Yu (2013) had indicated that consumers have different psychology in responding to advertisements while at home and while travelling. This implication is very much useful in providing location -based services to consumers in more customized way. Consumers prefer to provide their location- based information especially when they are on the go. The location-based advertisements facilitate and make consumers comfortable on their journeys by providing information to find food and lodging, tourist destinations, transportation, and other useful travelling tips. Sometimes, using a m-ad to search for information is a time-saving factor for eventful consumers.

The study of Sri Lanka consumers' attitude towards mobile advertising bares various implications for various stakeholders the industry. Authors' reviews highlights world mobile advertising industry is soaring; while it is very primitive in Sri Lankan content. Mobile-advertising is a promising market all over the world which generates high revenue continuously. eMarketer states even Google's total net ad revenue is rising due to mobile search. eMarketer estimated 14\% jump up ( $\$ 38.3$ billion in 2013 to $\$ 43.5$ billion in 2014) in Google's net ad revenue in 2014 where mobile search is gaining a significant share. Further, Google's Chief Business Officer pointed out that they would gain from the shift to mobiles since smartphones and tabs can capture more details of their users. In overall U.S mobile advertisements industry has gained a 122\% rise in 2013. Furthermore, UK reports that mobile advertising revenue will overtake the newspaper advertisements in 2014. Further, according to eMarketer UK advertising spend on digital will continue to soar between 2014 and 2017. As per Gartner, worldwide mobile advertising revenue is forecast to reach $\$ 24.5$ billion in 2016. Asian Pacific region countries are too rising rapidly in terms of mobile advertising usage. Japan, South Korea and China are the leading partners and India is expected to be. The mobile advertising market took off even faster than expected due to an increased uptake in smartphone and tablets, as well as the merger of consumer behaviors on computers and mobile devices (Stephaine Baghdassarian, Research Director at Gartner).

Results of this study and the worldwide scenario generates implications and opens up varied avenues to marketers, advertisers, software developers, service providers, regulatory bodies and researchers in Sri Lanka. First and foremost it should be mentioned that the results of the study are equivalent to market segmentation theories. Demographic variables and geographic variables are the basic segmentation variables which a marketer could use to segment his market (Kotler, 2005). The results show that smartphones are popular in Sri Lanka, especially among youngsters. But using mobiles as a media vehicle is elementary in Sri Lanka. Excessive usage of SMS based advertisements to attract the audience and educate them about mobile advertising would be an ideal step. This would increase the awareness level of mobile advertising among Sri Lankan consumers. Eventually, they will get use to other types of mobile advertising (with static/motion pictures, videos, interactive advertisements, in-app advertisements, etc). The most suitable target group is fallen between age 16 and 25 . This is par with other research findings too. Hence, females show more positive attitude toward mobile advertising, 
commencing m-advertising related to feminine category would be popular and yielding as well. Results indicate that lower income earners have more positive attitude towards mobile advertising. To attract this segment of the market, professionals have to avoid using complicated messages and English medium advertisements as well. Particularly, simple advertisements in native language would yield high results. Additionally, increasing user control, interactivity, and providing incentives would make mobile advertising popular among Sri Lankans. Professionals need to pay attention to consumers who use internet advertisements as well. This criterion could be really attractive for practitioners to create another target audience for mobile advertising. Finally, mobile advertising is important in green marketing perspective too which will reduce the usage of traditional forms of advertising which has negative environmental effects. From this perspective, the current research findings are meaningful for public policy makers equally.

The customization can increase the response rate to mobile advertising than that of traditional media. Mobile advertising could be customized easily as mobile media is highly interactive with the customer. In the context of permission marketing, it has been found that if a commercial message is personalized, it may be perceived as valuable information as opposed to "interrupt marketing" (Bhave et al., 2013). In the subject of SMS (Short Messaging Service) advertising/marketing, it helps to enrich the effectiveness of traditional advertising campaigns when they are coupled. When compared to SMS, MMS (Multi Media Messaging Service) can increase the effective rate of mobile advertising. MMS can accelerate the brand recall in consumers' memory with different effects embedded in the message itself and it would influence the purchase intention as well. Nevertheless, advertisers and marketers should handle SMS/MMS properly in promoting their thoughts to their customers as unnecessary SMS/MMS overloaded in consumers' mobile device can interrupt the customers' intention to use the mobile advertisements.

Advertisers and marketers got other viable options in the technologically evolving world to increase the acceptance rate of their mobile advertisement. QR (Quick Response) codes cold be identified as one of such contemporary tools that marketers can use. QR codes are one of highly and efficient tools that could be used to receive and send information in the extremely volatile marketing world. QR codes give fewer burdens to the user It is less time and effort consuming. Hence, such tools attract people with busy schedules and they scan QR codes easily and receive any amount of information which can be useful in their decision making. With the usage of QR codes consumers can search for any information within few seconds. Marketers and advertisers must be tactful enough to utilize such effective tools in mobile advertising in order to attract consumers with lesser efforts to outcompete the rigorous competition.

\section{Limitations and Future Research}

\subsection{Limitations}

The current study was limited to a very basic research framework. Four basic demographic variables namely age, gender, education level and family income was considered discover the relationship with the attitude toward mobile advertising. Additionally, the construct, experience with internet advertisements was tested. The study was limited to such an uncomplicated structure since the study is the pioneering study in Sri Lankan context. The literature from other countries was the foundation of the current study. Decisive predictors of attitude toward mobile advertising were not considered in this study as they are not appropriate in Sri Lankan context in the present. Eg: perceived usefulness, ease of use, informativeness, interactivity, entertaining. But, as Sri Lankan Mobile advertising industry is emerging, theories like Technology Acceptance Model (TAM) (Yang, 2007; Zhang \& Mao, 2008), Theory of Reasoned Action Model (Fishbein \& Ajzen,1995; Lee,Tsai, \& Jih, 2006; Lutz, MacKenzie \& Belch, 1983; Tsang et al., 2004), Web Advertising Model (Choi \& Rifon, 2002; Ducoffe, 1995; Wang \& Sun 2002) could be applied in future studies in order to discover insights of behavioral aspects of Mobile advertising .

\subsection{Future Research}

Since this is the pioneering study about mobile advertising in Sri Lanka, there are ample of avenues for further research studies. Smartphone are fetching widely and then sampling framework could be broadened. Plenty of studies could be carried out to explore the behavioral aspects of mobile advertising. Enormous array of literature from developed countries and other developing countries could be considered and related to such studies. Perhaps, constructive studies and their outcomes would pave the path for mobile advertising to be widely mobilized and thereof further research needs will be emerged. Sri Lankan consumers' behavioral characteristics, testing above mentioned theories related to mobile advertising, exploring determinants/predictors of mobile advertising ' acceptance, etc would be attractive research study areas in Sri Lankan context. Possibly, new theories would be emerged in the context of Sri Lanka related to mobile advertising. 


\subsubsection{In-Depth Research in M-ad Characteristics Using Advanced Theories}

The findings of the study highlight various areas to investigate further in Sri Lankan context. Advanced theories like Technology Acceptance Model (TAM), Uses and Gratification theory (U \& G) Flow theory and Theory of Reasoned Action (TRA) could be tested in this emerging market and explore the behavioral outcomes of consumers toward mobile advertising. Technological aspects of mobile advertising should be given attention and observe how technological factors behave in relatively new markets like Sri Lanka. Additionally, further research is needed in order to discover mostly attractive features of mobile advertising. Since there is a need for superior $\mathrm{M}$-ad designs to meet fragmented needs and wants of a contemporary customer, new research work is needed in this aspect. Eg: Ad language, Ad timing, Ad frequency, Ad pictures (static/motion), Ad placement, In-app advertisements, Location-based advertisements and so forth. Gaining better insights of these characteristics would support to design better-personalized Mobile advertising to the customer with less irritation.

9.2.2 In-Depth Research in Product/Service Attributes or Brands

Being a new market for mobile advertising, Sri Lankan Mobile advertising industry should do plenty of homework before implementing mobile advertising in mass scale. The Industry must look into various aspects of mobile advertising characteristics in order to make mobile advertising popular in Sri Lanka. Therefore, another aspect, which is imperative, is brand or product features. This perspective would be in great need to be explored for marketers to develop customized strategies and tactics in consumers' mobile device. More work need to be done in searching most suitable attributes of brands to advertise via mobile advertising. Furthermore, what types of products/services/brands are mostly suited for mobile advertising should be determined. Thus, it would be very fruitful to fragment the research work into many more areas that will enrich the literature about mobile advertising in Sri Lanka.

\subsubsection{In-Depth Research in Different Consumer Groups}

The present study has been limited mostly to young generation in Sri Lanka. More work is needed in understanding different types of consumers and their complex behaviour related to mobile advertising. Therefore, deploying consumer behavior theories or merging such theories with theories related to technology to produce viable outcomes which could be implemented by marketers. Results of such types of studies would yield better outcomes from mobile advertising. Additionally, examining behavior of different consumers groups (eg: demographically differentiated groups) would comfort marketers to design better-personalized advertisements.

\section{References}

Abbad, M., Abed, J. M., \& Abbad, M. (2012). The Development of E-Banking in Developing Countries in the Middle East. Journal of Finance, Accounting and Management, 3(2), 107-123.

Abdullah, S., Al-Somali, G. R., \& Clegg, B. (2009). An investigation into the acceptance of online banking in Saudi Arabia. Technovation, 29,130-141. http://dx.doi.org/10.1016/j.technovation.2008.07.004

Ajzen, I., \& Fishein, M. (2005). The influence of attitudes on behavior. Retrieved from http://www.researchgate.net/publication/264000974

Alwitts, L. F., \& Prabhaker, P. R. (1992). Functional and belief dimensions of attitudes to television. Journal of Advertising Research, 32(5), 30-42.

Balabanis, G., \& Vassileiou, S. (1999). Some Attitudinal Predictors of Home-Shopping through The Internet. Journal of Marketing Management, 15, 361-385. http://dx.doi.org/10.1362/026725799784870315

Banerjee, S., \& Dholakia, R. R. (2012). Location-based mobile advertisements and gender targeting. Journal of Research in Interactive Marketing, 6(3), 198-214. http://dx.doi.org/10.1108/17505931211274679

Bhatnagar, A. (2007). Do determinants of online shopping differ for personal shoppers and professional shoppers? EuroMed Journal of Business, 2(1), 87-102. http://dx.doi.org/10.1108/14502190710749974

Bhave, K., Jain, V., \& Roy, S. (2013). Understanding the orientation of Gen Y toward mobile applications and In-app advertising in India. International Journal of Mobile Marketing, 8(1), 62-74.

Botetzagias, L., Dima, A-F., \& Malesios, C. (2015). Extending the Theory of Planned Behaviour in the context of recycling: The role of moral norms and of demographic predictors. Resources, Conservation and Recycling, 95, 58-67. http://dx.doi.org/10.1016/j.resconrec.2014.12.004

Chen, P. T., Cheng, J. Z., Yu, Y. W., \& Ju, P. H. (2014). Mobile advertising setting analysis and its strategic implications. Technology in Society, 39, 129-141. hhtp://dx.doi:.org/10.1016/j.techsoc.2014.09.004

Choi, S. M., \& Rifon, N. J. (2002). Antecedents and consequences of Web advertising credibility: A study of 
consumer response to banner advertisements. Journal of Interactive Advertising, 3(1), 12-24. http://dx.doi.org/10.1080/15252019.2002.10722064

Coursaris, C. K., \& Sung, J. (2012). Antecedents and consequent of a mobile website's interactivity. New media and Society, 14(7), 1128-1146. http://dx.doi.org/10.1177/1461444812439552

Dhaliwal, J. (2003). The youth cultural icon of the 21st century. Young Consumers, 4(1), 29-34. http://dx.doi.org/10.1108/17473610310813690

Ducoffe, R. H. (1995). How consumers asses the values of advertising. Journal of Current Issues \& Research in Advertising, 1-18. http://dx.doi.org/10.1080/10641734.1995.10505022

Dutta-Bergman, M. J. (2006). The demographics and psychographics antecedents of attitude towards advertising. Journal of Advertising Research March, 102-112. http://dx.doi.org/10.2501/S0021849906060119

Friedrich, R., Grone, F., Holbling, K., \& Peterson, M. (2009). The march of mobile marketing: New chances for consumer companies, new opportunities for mobile operators. Journal of Advertising Research, (March), 54-61. http://dx.doi.org/10.2501/S0021849909090096

Gao, Q. P. L., Rau, P., \& Salvendy, G. (2010). Measuring perceived interactivity of mobile advertisements. Behavior \& Information Technology, 29(1), 35-44. http://dx.doi.org/10.1080/01449290802666770

Gao, T., Rohm, A. J., Sultan, F., \& Huang, S. (2012). Antecedents of consumer attitudes toward Mobile Marketing: A Comparative Study of Youth Markets in the United States and China. Thunderbird International Business Review, 54(2). http://dx.doi.org/10.1002/tie.21452

Goggin, G. (2013). Youth culture and mobiles. Mobile Media and Communication, 1(1), 83-88. http://dx.doi.org/10.1177/2050157912464489

Gong, W., Stump, R. L., \& Maddox, L. M. (2013). Factors influencing consumers' online shopping in China. Journal of Asia Business Studies, 7(3), 214-230. http://dx.doi.org/10.1108/JABS-02-2013-0006

Hanley, M., Becker, M., \& Martinsen, J. (2006). Factors influencing mobile advertising acceptance: will incentives motive college students to accept mobile advertisements. International Journal of Mobile Marketing, 1(1), 50-58.

Hansen, T. (2005). Consumer adoption of online grocery buying: a discriminant analysis. International Journal of Retail \& Distribution Management, 33(2), 1-12. http://dx.doi.org/10.1108/09590550510581449

Haste, H. (2005). Joined\#up texting: mobile phones and young people. Young Consumers, 6(3), 56-67. http://dx.doi.org/10.1108/17473610510701214

Haverila, M. (2011). Behavioral aspects of cell phone usage among youth: an exploratory study. Young Consumers, 12(4), 310-325. http://dx.doi.org/10.1108/17473611111185869

Hawkins, I., Best, R. J., \& Coney, K. A. (1998). Consumer behavior: Building marketing strategy. New York: Irwin/McGraw Hill.

Hernandez, B., Jimenez, J., \& Martın, M. J. (2011). Age, gender and income: do they really moderate online shopping behaviour? Online Information Review, 35(1), 113-13. http://dx.doi.org/10.1108/14684521111113614

Hor-Meyll, L. F., De Lima, M. C., \& Ferreira, J. B. (2014). Why should I accept advertisements on my Mobile Phone? Factors affecting the acceptance by Brazilian teenagers. Brazilian Business Review, 11(4), 130-150. http://dx.doi.org/10.15728/bbr.2014.11.4.6

Hui, T. K., \& Wan, D. (2007). Factors affecting Internet shopping behavior in Singapore: gender and educational

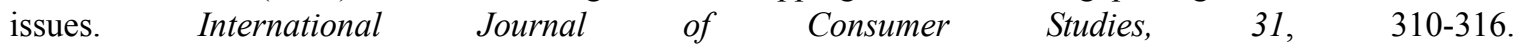
http://dx.doi.org/10.1111/j.1470-6431.2006.00554.x

Ismail, M. A., \& Osman, M. A. Y. (2012). Factors Influencing the Adoption of E-banking in Sudan: Perceptions of Retail Banking Clients. Journal of Internet Banking and Commerce, 17(3).

Kim, J. (2012). Developing an Empirical Model of College Students' Online Shopping Behavior. The International Journal of Interdisciplinary Social Sciences, 6(10), 821-109.

Kim, K. Y., \& Lee, B. G. (2014). Marketing insights for mobile advertising and consumer segmentation in the cloud era: A Q-R hybrid methodology and practices. Technological Forecast Change. http://dx.doi.org/10.1016/j.techfore.2014.01.011 
Kim, Y., Briley, D. A., \& Ocepek, M. G. (2015). Differential innovation of smartphone and application use by socio demographics and personality. Computers in Human Behavior, 44, 141-147. http://dx.doi.org/10.1016/j.chb.2014.11.059

Kotler P., \& Amrstron, G. (2009). Principles of Marketing. Pearson Education Asia Ltd and Tsinghua University Press, 123.

Kwon, W. S., \& Noh, M. T. (2010). The influence of prior experience and age on mature consumers' perceptions and intentions of internet apparel shopping. Journal of Fashion Marketing and Management, 14(3), 335-349. http://dx.doi.org/10.1108/13612021011061825

Lee, S. F., Tsai, Y. C., \& Jih, W. J. (2006). An empirical examination of Customer perception of mobile advertising. Information Resources Management Journal, 19(4), 39-55. http://dx.doi.org/10.4018/irmj.2006100103

Leek, S., \& Christodoulides, G. (2009). Next-generation mobile marketing: How young consumers react to Bluetooth-enabled advertising. Journal of Advertising Research. http://dx.doi.org/10.2501/S0021849909090059

Leppaniemi, M., \& Karjaluoto, H. (2008). Exploring the effects of gender, age, income and employment status on consumer response to mobile advertising campaigns. Journal of System and Information Technology, 10(3), 251-265. http://dx.doi.org/10.1108/13287260810916943

Liu, C. L., Sinkovics, R. R., Pezderka, N., \& Haghirian, P. (2012). Determinants of consumer perceptions toward mobile advertising-A comparison between Japan and Austria. Journal of Interactive Marketing, 26, 21-32. http://dx.doi.org/10.1016/j.intmar.2011.07.002

Lutz, R. J., MacKenize, S. B., \& Blech, G. E. (1983). Attitude toward the ad as a mediator advertising effectiveness: Determinants and consequences. Advances in Consumer Research, 10(1), 532-539.

Maenpaa, K., Kale, S. H., Kuusela, H., \& Mesiranta, N. (2008). Consumer perceptions of Internet banking in Finland: The moderating role of familiarity. Journal of Retailing and Consumer Services, 15, 266-276. http://dx.doi.org/10.1016/j.jretconser.2007.05.007

Mobile Marketing Association. Retrieved from mmaglobal.com/news/mma-updates-definition-mobile-marketing

Mokbel, M. F., \& Levandoski, J. J. (2009/June). Toward context and preference-aware location-based services. In Proceedings of $8^{\text {th }}$ ACM International Workshop on Data Engineering for Wireless and Mobile Access, pp. 25-32.

Monsuwe, T. P., Dellaert B. G. C., \& Ruyter, K. D. (2004). What drives consumers to shop online? A literature review. International Journal of Service Industry Management, 15(1), 102-121. http://dx.doi.org/10.1108/09564230410523358

Morganosky, M. A., \& Cude, B. J. (2000). Consumer response to online grocery shopping. International Journal of Retail \& Distribution Management, 28(1), 17-26. http://dx.doi.org/10.1108/09590550010306737

Muk, A. (2007). Consumer's intention to opt in to SMS advertising. International Journal of Advertising, 26(2), 177-198.

Ndung'u, M. N., Waema, T. M., \& Mitullah, W. V. (2012). Factors influencing usage of new technologies in low-income households in Kenya: the case of Nairobi. Info, 14(4), 52-64. Emerald Group Publishing Limited. http://dx.doi.org/10.1108/14636691211240888

Nittala, R. (2011). Registering for incentivized mobile advertising: Discriminant analysis of mobile users. International Journal of Mobile Marketing, 6(1), 42-53.

Okazaki, S., Katsukura, A., \& Nishiyama, M. (2007). How mobile advertising works: the role of trust in improving attitudes and recall. Journal of Advertising Research, 47, 165-178. http://dx.doi.org/10.2501/S0021849907070195

Pang, C., Yen, C. D., \& Tarn, J. M. (2007) Exploring online shoppers' e-trust in China. Human Systems Management, 26, 193-198.

Peters, C., Amato, C. H., \& Hollenbeck, C. R. (2007). An exploratory investigation of consumers' perception of $\begin{array}{lllll}\text { wireless advertising. Journal of } & \text { Advertising, } & 36(4), & 129-145 .\end{array}$ http://dx.doi.org/10.2753/JOA0091-3367360410

Porter, G., Hampshire, K., Abane, A., Munthali, A., Robson, E., Mashiri, M., \& Tanle, A. (2012). Youth, mobility 
and mobile phones in Africa: findings from a three-country study. Information Technology for Development, 18(2), 145-162. http://dx.doi.org/10.1080/02681102.2011.643210

Punj, G. (2011). Effect of Consumer Beliefs on Online Purchase Behavior: The Influence of Demographic Characteristics and Consumption Values. Journal of Interactive Marketing, 25(3), 134-144. http://dx.doi.org/10.1016/j.intmar.2011.04.004

Punj, G. (2012). Income effects on relative importance of two online purchase goals: Saving time versus saving money? Journal of Business Research, 65, 634-640. http://dx.doi.org/10.1016/j.jbusres.2011.03.003

Rohm, A. J., Gao, T., Sultan, F., \& Pagani, M. (2012). Brand in the hand: A cross-market investigation of consumer acceptance of mobile marketing. Business Horizon, 55, 485-493. http://dx.doi.org/10.1016.j.bushor.2012.05.004

Rosenkrans, G., \& Myers, K. (2012). Mobile advertising effectiveness. International Journal of Mobile Marketing, 7(3), 5-21.

Seyal, A. H., \& Rahim, M. (2011). Customer Satisfaction with Internet Banking in Brunei Darussalam: Evaluating the Role of Demographic Factors. e-Service Journal, 7(3), 47-68. http://dx.doi.org/10.2979/eservicej.7.3.47

Shavitt, S., Lowery, P. M., \& Haefner, J. E. (1998). Public attitudes toward advertising: more favorable than you might think. Journal of advertising Research, 38(4), 7-22.

Speck, P. S., \& Elliot, M. T. (1997). Predictors of Advertising avoidance in print and broadcast media. Journal of Advertising, 26(3), 61-76. http://dx.doi.org/10.1080/00913367.1997.10673529

Sun, S., \& Wang, Y. (2010). Familiarity, Beliefs, Attitudes and consumer Reponses toward online advertising in China and United States. Journal of Global Marketing, 23, 127-138. http://dx.doi.org/10.1080/08911761003673454

Sundaram, D. S., \& Taylor, R. D. (1998). An Investigation of External Information Search Effort: Replication In In-home Shopping Situation. Advances in Consumer Research, 25, 440-445.

Thamizhvanan, A., \& Xavier, M. J. (2013). Determinants of customers' online purchase intention: an empirical study in India. Journal of Indian Business Research, 5(1), 17-32. http://dx.doi.org/10.1108/17554191311303367

Thompson, K., Griffith, E., \& Leaf, P. (1990). A historical review of the Madison model of community care. Hospital and Community Psychiatry, 41(6), 21-35. http://dx.doi.org/10.1176/ps.41.6.625

Tsang, M. M., Ho, S. C., \& Liang, T. P. (2004). Consumer attitudes toward mobile advertising: an empirical study. International Journal of Electronic Commerce, 8(3), 65-78.

Unal, S., Ercis, A., \& Keser, E. (2011). Attitudes towards mobile advertising-A research to determine the differences between the attitudes of youth and adults. Procedia Social and Behavioral Sciences, 2, 361-377. http://dx.doi.org/10.1016/j.sbspro.2011.09.067

Vrechopoulos, A. P., Siomkos, G. J., \& Doukidis, G. I. (2001). Internet shopping adoption by Greek consumers. $\begin{array}{llll}\text { European Journal of Innovation } & \text { Management, } & 4(3), & \text { 142-153. }\end{array}$ http://dx.doi.org/10.1108/14601060110399306

Walsh, S., White, K. M., \& Young, R. McD. (2009). The Phone Connection: A Qualitative Exploration of How Belongingness and Social Identification Relate to Mobile Phone Use Amongst Australian Youth. Journal of Community \& Applied Social Psychology, 19, 225-240. http://dx.doi.org/10.1002/casp.983

Wang, Y. J., \& Sun, S. (2010). Examining the role of beliefs and attitudes in online advertising: A comparison between the USA and Romania. International Marketing Review, 27(1), 87-107. http://dx.doi.org/10.1108/02651331011020410

Wu, S. L. (2003). The relationship between consumer characteristics and attitude toward online shopping. Marketing Intelligence \& Planning, 21(1), 37-44. http://dx.doi.org/10.1108/02634500310458135

Yang, B., Kim, Y., \& Yoo, C. (2013). The integrated mobile advertising model: The effects of technology- and emotion-based evaluations. Journal of Business research, 66, 1345-1352, http://dx.doi.org/10.1016/j.jbusres.2012.02.035

Yang, K. C. C. (2007). Exploring factors affecting consumer intention to use mobile advertising in Taiwan. Journal of International Consumer Marketing, 20(1), 33-49. http://dx.doi.org/10.1300/J046v20n01_04 
Yu (Hyunjae), J. (2013). You've got mobile advertisements! Young consumers' responses to mobile advertisements with different types of interactivity. International Journal of Mobile Marketing, 5-22.

http://www.emarketer.com

http://www.gartner.com/resId=2247015

http://www.hipcricket.com

\section{Copyrights}

Copyright for this article is retained by the author(s), with first publication rights granted to the journal.

This is an open-access article distributed under the terms and conditions of the Creative Commons Attribution license (http://creativecommons.org/licenses/by/3.0/). 